\title{
Case-finding for alpha1-antitrypsin deficiency in Kazakh patients with COPD
}

\author{
Ardak Zhumagaliyeva', Stefania Ottaviani², Timm Greulich³, Marina Gorrini², Claus Vogelmeier ${ }^{3}$, \\ Ludmila Karazhanova', Gulmira Nurgazina ${ }^{5}$, Annalisa DeSilvestriं ${ }^{6}$, Victor Kotke ${ }^{3}$, Valentina Barzon², \\ Michele Zorzetto ${ }^{2}$, Angelo Corsico ${ }^{2,4+}$ and Ilaria Ferrarotti ${ }^{1,4^{*}+}$
}

\begin{abstract}
Background : Alpha-1-antitrypsin deficiency (AATD) is an under-diagnosed condition in patients with chronic obstructive pulmonary disease (COPD). The aim of this study was to screen for AATD in Kazakh patients with COPD using dried blood spot specimens.

Methods: The alpha1-antitrypsin (AAT) concentration was determined by nephelometry, PCR was used to detect PiS and $\mathrm{PiZ}$ alleles; and isoelectric focusing was used to confirm questionable genotype results and detect rare AAT variants.

Results: To this aim, 187 Kazakh subjects with COPD were recruited. Blood samples were collected as dried blood spot. Genotyping of 187 samples revealed 3 (1.6\%) PI*MZ and 1 (0.53\%) PI*MS, Phenotyping identified also two sample (1.1\%) with phenotype PiMl. Allelic frequencies of pathological mutations Z, S and I resulted $0.8 \%, 0.3 \%, 0.5 \%$, respectively, in COPD Kazakh population.

Conclusion: This study proved that AATD is present in the Kazakh population. These results support the general concept of targeted screening for AAT deficiency in countries like Kazakhstan, with a large population of COPD patients and low awareness among care-givers about this genetic condition.
\end{abstract}

Keywords: Alpha-1 antitrypsin, Chronic obstructive pulmonary disease, Genetics, Genotype, Orphan disease

\section{Background}

Chronic obstructive pulmonary disease (COPD) is a principal cause of morbidity and mortality. In 2008, COPD was ranked fourth as a leading cause of death worldwide, and the number of patients is still increasing. The World Health Organization (WHO) predicts that COPD will reach third among the most common causes of mortality by 2030 [1]. In Kazakhstan, the number of patients with COPD has increased more than twofold in the last 10 years, with an incidence of 321 out of 100 thousand people in 2011 [2].

Alpha1-antitrypsin deficiency (AATD), the most widely recognized genetic disorder causing COPD [3, 4] was first reported in 1963 by Carl-Bertil Laurell and his fellow investigator Sten Eriksson, who detected the lack of a normal alpha1-band on plasma protein electrophoresis in two

\footnotetext{
* Correspondence: i.ferrarotti@smatteo.pv.it

${ }^{\dagger}$ Equal contributors

${ }^{1}$ Semey State Medical University, Semey, Kazakhstan

${ }^{4}$ Dept of Internal Medicine and Therapeutics, Pneumology Unit, University of

Pavia, Pavia, Italy

Full list of author information is available at the end of the article
}

emphysematous patients [5]. After this initial discovery, over 100 variants of alpha 1-antitrypsin (AAT) have been detected; these have been characterized as different genetic variants. Subsequent studies on the prevalence of these variants have greatly contributed to our understanding of the epidemiology of the disorder.

Alpha1-antitrypsin is a $52-\mathrm{kDa}$ glycoprotein produced by hepatocytes and, to a lesser extent, by mononuclear monocytes. Its main function is to protect the lung against proteolytic damage by neutrophil elastase [6]. The AAT protein is encoded by the SERPINA1 gene, which is situated on the long arm of chromosome 14 (14q31-32.3). This gene spans $12.2 \mathrm{~kb}$ and is organized into four coding (II, III, IV and V) and three non-coding (Ia, Ib and Ic) exons. The encoded protein includes 394 amino acids, with its reactive center loop corresponding to methionine-358 [7]. AAT inhibits several serine proteinases, but its preferred target is neuthrophil elastase (NE), a 29- kDa neutrophil enzyme that facilitates elastin degradation and lung tissue injury and destruction. When neutrophils are activated, preformed NE 
is secreted into the lung tissue. Normal AAT plasma levels (1-2 g/L) protect lungs from NE attack, binding the enzyme to the AAT active site and constantly inactivating the enzyme [8]. The pathophysiology of AAT is associated with mutations in the PI locus [9]. The most common deficiency allele is the $\mathrm{Z}$ allele (rs28929474) which, in the homozygous state (PiZZ), is associated with AAT plasma levels that are $85 \%$ less than normal. The $\mathrm{S}$ allele (rs17580) is associated with AAT plasma levels that are nearly $40 \%$ less than normal in the homozygous state [10]. The normal allele, usually called $\mathrm{M}$, is characterized by an AAT plasma level that falls within general population normal ranges.

Epidemiological studies have shown that the highest prevalence of PI*ZZ related AATD is among Northern Europeans and populations with a Northern European background (8). Nevertheless, during the last few years, based on evaluations of allele frequencies in available cohort studies, it has been suggested that the $\mathrm{Z}$ variant is not only common in Caucasians, but also among other ethnic groups worldwide $[11,12]$. Furthermore, there are at least 30 AAT alleles other than the PI*Z and PI*S alleles which are associated with significantly reduced or absent plasma AAT levels. Given the extreme rarity of such variants, often described in the literature as single case reports, little is known about their epidemiology, especially in countries where this disorder is largely under-diagnosed [13].

As an under-diagnosed disorder, the latest AATD guidelines by both the World Health Organization and the American Thoracic Society/European Respiratory Society recommend the establishment of screening programs to detect AATD in patients with COPD. It is rationalized that the coincidental identification of AATD would motivate family screening, while improving appropriate management, and specific counseling for these patients and families [14].

Even though AATD is as a whole, one of the most common hereditary disorders worldwide, its frequency varies markedly from one country to another [15-17] and affects many different racial subgroups. In particular, AATD has spread significantly throughout the continent of Asia [18]. Therefore, with this study we aimed to detect AAT deficiency in Kazakh COPD patients.

\section{Methods}

\section{Study subjects}

After approval by the local Ethical Committee (№2, 13.11.2013), all compliant COPD patients referred to the Pulmonary Disease Department in Emergency Hospital of Semey (East Kazakhstan region) from June 2014 to August 2014 and from July 2015 to September 2015 were enrolled in the present study. The analysis was conducted in two major European reference centers for AATD: Centre for research alpha-1-antitrypsin deficiency, Marburg, Germany and Center for Diagnosis of Inherited Alpha1-antitrypsin deficiency, Institute for Respiratory Disease, Pavia, Italy.
According to the protocol: Global Initiative for Chronic Obstructive Lung Disease (GOLD) [19], COPD diagnosis was confirmed by spirometry with $\mathrm{FEV}_{1} / \mathrm{FVC}$ values $<0.7$, where $\mathrm{FEV}_{1}=$ forced expiratory volume in one second and $\mathrm{FVC}=$ forced vital capacity. Pre-bronchodilator spirometric tests were performed according to ERS guidelines with a rolling seal spirometer followed by post bronchodilator spirometric tests after inhalation of $400 \mathrm{mg}$ salbutamol [20]. After a targeted physical examination, data on patient symptoms were collected. Smoking history was calculated in pack/years as the product of tobacco use (in years) and the average number of cigarettes smoked per day/20 [21].

Capillary blood samples were collected on filter paper. Blood was obtained by pricking a distal finger tip and blotting onto filter paper. The papers were then airdried at room temperature and stored at $4{ }^{\circ} \mathrm{C}$ in separate envelopes to avoid cross contamination.

\section{Quantitative determination of AAT level}

The AAT level measurements were performed on dried blood spot (DBS) samples by a rate immune nephelometric method (Dade-Behring BN II, Germany and Immage 800 Immunochemistry System - (Beckman-Coulter, USA) [9, 22].

\section{Genotyping and phenotyping}

DNA extracted from the DBS of all subjects by standard methods was submitted to genotyping for $\mathrm{Z}$ and S SERPINA1 alleles [23, 24]. Qualitative detection and characterization of AAT phenotypes was carried out by IsoElectroFocusing (IEF) using the Hydrasys electrophoresis platform and the Hydragel 18 AAT Isofocusing kit (Sebia, Spain) [25].

\section{Statistical analysis}

Data were analyzed using the Statistical Package for the Social Sciences version 20, (SPSS, USA, Chicago, IL). Descriptive statistics were used to analyse data. For continuous variables, the mean, standard deviation (SD), median, minimum and maximum values were calculated.

\section{Results}

One hundred eleven subjects with COPD (group 1) were enrolled during the period from June to August 2014 and analysed in Germany. Among those, 64 were male and 47 female, the mean age was 60.7 years (SD 11.3; range 2179). The large majority of patients were non-smokers (54.05\%), current and former smokers were $34.2 \%$ and $10.8 \%$ respectively. Seventy-six Kazakh subjects (26 male, 50 female) with COPD (group 2) were enrolled during the period from July to September - 2015 and analyzed in Italy. Their mean age was 57.7 years (SD 13.03; range 2479). The percentage of non-smokers was $64.5 \%$, current and former smokers were $22.4 \%$ and $10.8 \%$ respectively. Table 1 summarizes the characteristics of the two groups 
Table 1 Patient demographic characteristics, spirometric values and clinical data

\begin{tabular}{|c|c|c|}
\hline & Group 1 & Group 2 \\
\hline N & 111 & 76 \\
\hline Age (years) $\div$ mean $(S D)$ & $60.7(11.3)$ & $57.98(11.03)$ \\
\hline Male \% & 57.6 & 34.2 \\
\hline BMI $\left(\mathrm{kg} / \mathrm{m}^{2}\right) \div$ mean $(\mathrm{SD})$ & $22.14(4,33)$ & $21.92(3,8)$ \\
\hline $\mathrm{FEV}_{1} / \mathrm{FVC}^{\mathrm{a}}$ & $0.56(0.16-0.68)$ & $0.57(0.26-0.69)$ \\
\hline $\mathrm{FEV}_{1} \%$ Predicted $^{\mathrm{a}}$ & $65(18-78)$ & $65(25-77)$ \\
\hline FVC $(\%)^{\mathrm{a}}$ & $66(12)(1.66-5,12)$ & $60(11,9)(1.66-5.12)$ \\
\hline MRC (score) $)^{\mathrm{a}}$ & $2(0-4)$ & $2(0-4)$ \\
\hline CAT (score) $)^{a}$ & $28(4-40)$ & $15(5-40)$ \\
\hline Current/former/non smoker (\%) & $34.2 / 10.8 / 54.05$ & $22.4 / 10.8 / 64.5$ \\
\hline Pack/year $\div$ (years) mean (SD) & $14.48(23.75)$ & $8.78(13.48)$ \\
\hline
\end{tabular}

SD Standard deviation; ${ }^{\mathrm{a}}$ median, lowest value and highest value; MRC Medical research council scale, CAT- COPD assessment test of samples. No statistically significant demographic or clinical variations were revealed between the two groups. All the COPD patients belonged to the Semey area in the north-east of Kazakhstan (Fig. 1).

Mean AAT plasma concentrations were $1.04 \mathrm{~g} / \mathrm{l}$ (SD 0.45 ; range 0.57-2.25) and $1.24 \mathrm{~g} / \mathrm{l}$ (SD 0.42; range $0.30-3.41)$ in groups 1 and 2 respectively. $S$ and $\mathrm{Z}$ allele genotyping allowed the detection of two $\mathrm{PI}^{*} \mathrm{MZ}$, and one $\mathrm{PI}{ }^{*} \mathrm{MS}$ in group 1 and one $\mathrm{PI}{ }^{*} \mathrm{MZ}$ in group 2 . By applying the cut - off concentrations used in the German and Italian Centers $(1.04 \mathrm{~g} / \mathrm{L}$ and $1.2 \mathrm{~g} / \mathrm{L}$, respectively), we performed IEF [25] in 43 samples from group 1 and 24 samples from group 2 (Fig. 2).

The phenotyping analysis of these samples, confirmed the genotyping results for samples carrying a $\mathrm{PI}^{*} \mathrm{MZ}$ or PI*MS genotype and revealed two subjects with a PIMI phenotype in group 1 (Fig. 1). Genotype and allele frequencies are reported in Table 2. Demographic and clinical data of patients with AAT deficiency, as established by genotyping and phenotyping are reported in Table 3.

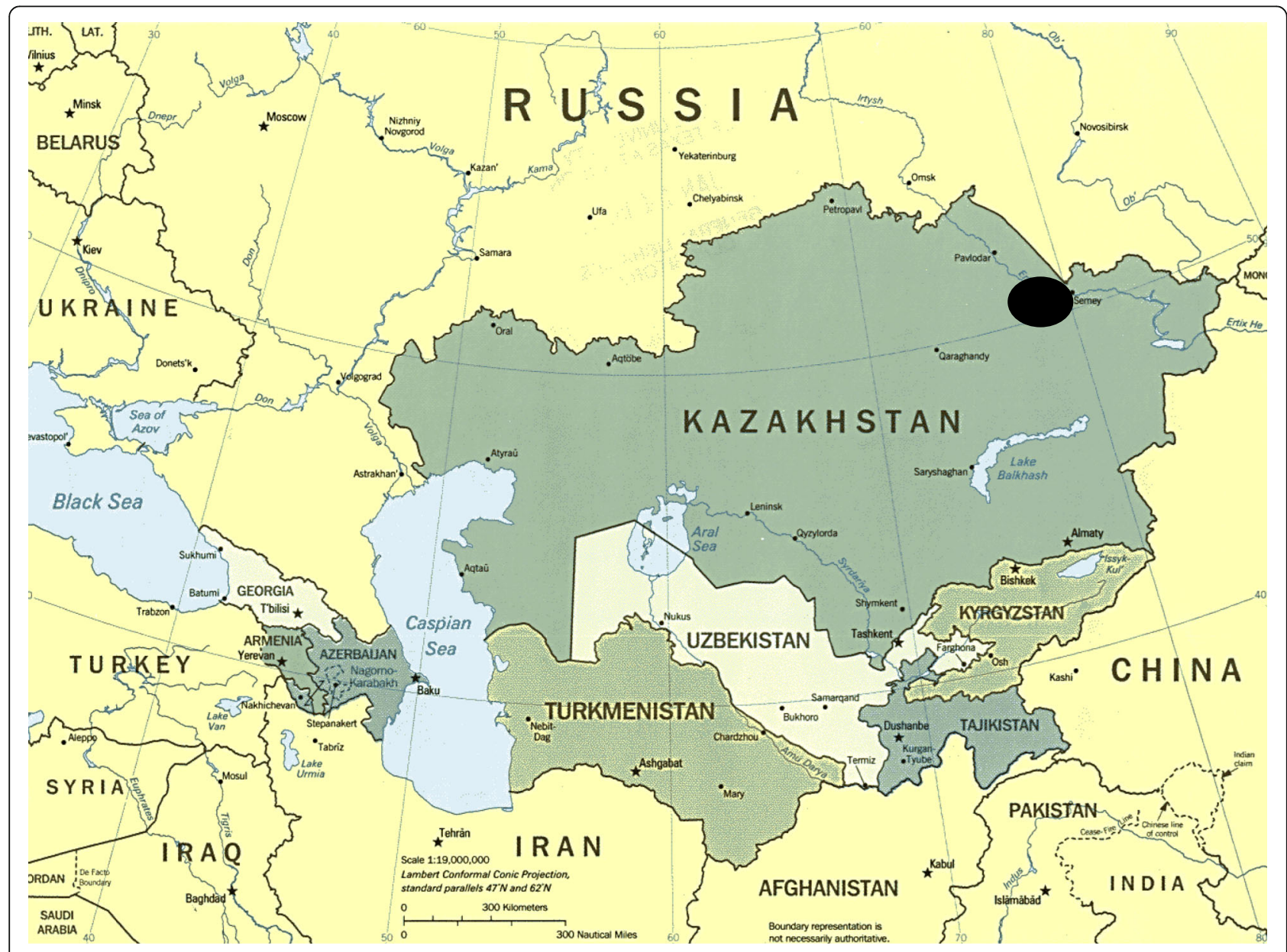

Fig. 1 Geographic map of Kazakhstan. The black circle indicates the area of Semey, where the COPD patients object of the present study have been recruited 


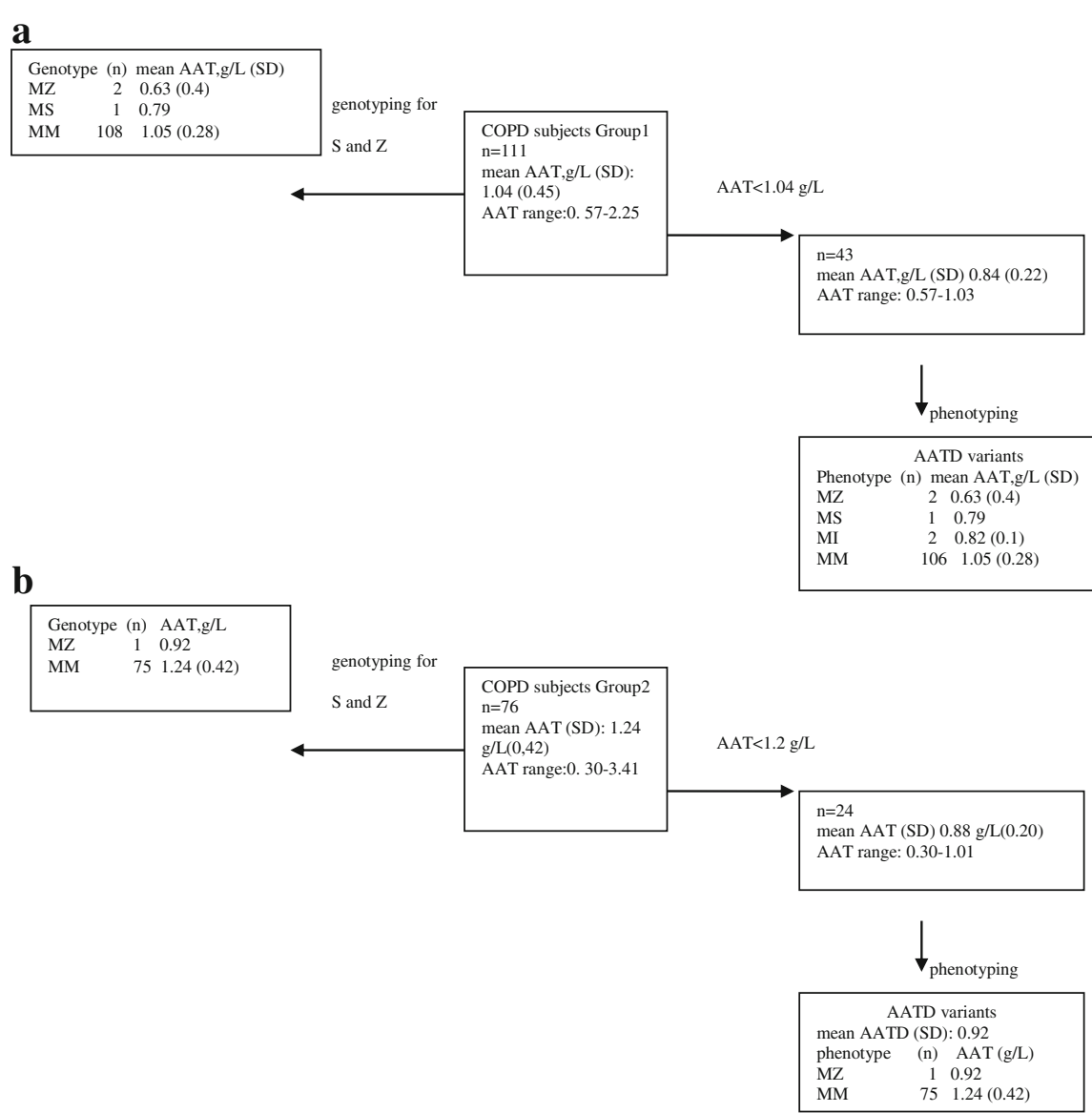

Fig. 2 Schematic representation of the genotyping/phenotyping results in groups 1 (a) and 2 (b)

\section{Discussion}

In Asian populations a systematic review of published data showed that SERPINA1 PI*S and PI*Z deficiency alleles are very rare, as also recently reported by de Serres and Blanco [26] in a genetic epidemiology study investigating AAT deficiency in the major geographic regions worldwide. Although this comprehensive study

Table 2 Frequency of AAT genotypes and alleles in the study population

\begin{tabular}{llll}
\hline & Group 1 (\%) & Group 2 (\%) & Total (\%) \\
\hline Pl*MM $^{*}$ & 95.5 & 98.7 & 96.8 \\
$\mathrm{PI}^{*} \mathrm{MS}$ & 0.9 & - & 0.5 \\
$\mathrm{PI}$ MZ & 1.8 & 1.3 & 1.6 \\
$\mathrm{PI}$ MI & 1.8 & - & 1.1 \\
M allele & 97.7 & 99.3 & 98.4 \\
S allele & 0.4 & - & 0.3 \\
Z allele & 0.9 & 0.7 & 0.8 \\
I allele & 0.9 & - & 0.6 \\
\hline
\end{tabular}

has potential biases, especially in regions with different ethnic or racial groups, it clearly pointed out the low frequency of $\mathrm{S}$ and $\mathrm{Z}$ alleles in Northern and Central Asian countries, with the exception of Saudi Arabia. According to the study, PI*S frequencies range from 0.0 in Nepal and Kazakhstan to 31 per 1000 inhabitants in Saudi Arabia; whereas, PI*Z frequencies range from less than 1 in Nepal, India, Jordan and Israel to 15 in Saudi Arabia.

Studies on AAT deficiency as a cause of COPD have only rarely been performed in Asian countries. A study on 356 COPD patients and 185 healthy controls demonstrated a higher frequency for $\mathrm{S}$ and $\mathrm{F}$ alleles in the COPD group compared with controls, although their frequencies were very low $(0.017$ and 0.014 respectively) [27]. In China, electrophoretic analysis of 748 normal subjects and 414 COPD patients did not detect any $\mathrm{S}$ or $\mathrm{Z}$ mutations in either COPD group [28], nor were any $S$ or $Z$ variants identified in a Korean study on 56 male emphysematous patients over 50 years old [29]. Likewise, in Iran, an investigation of 130 COPD patients detected 
Table 3 Demographic and clinical data of patients with AAT deficiency

\begin{tabular}{|c|c|c|c|c|}
\hline & PIMZ & PIMS & PIMI & Total \\
\hline N & 3 & 1 & 2 & 6 \\
\hline Age (years) $\div$ mean $(S D)$ & $59(16.9)$ & 62 & $51(2)$ & $56.8(12.7)$ \\
\hline Male \% & 33.3 & 100 & 50 & 50 \\
\hline BMI $\left(\mathrm{kg} / \mathrm{m}^{2}\right) \div$ mean $(\mathrm{SD})$ & $22.7(0,9)$ & 18 & $25(2.5)$ & $21.2(2.3)$ \\
\hline $\mathrm{FEV}_{1} / \mathrm{FVC} \div$ mean (SD) & $0.48(0.2)$ & 0.34 & $0.48(0.02)$ & $0.47(0.6)$ \\
\hline $\mathrm{FEV}_{1} \%$ Predicted $\div$ mean $(\mathrm{SD})$ & $46.5(2.1)$ & 40 & $48.5(0.7)$ & $48(4.5)$ \\
\hline FVC(\%) $\div$ mean (SD) & $51.3(4.05)$ & 47 & $49.5(3.5)$ & $2.9(0.2)$ \\
\hline MRC (score) $\div$ mean (SD) & 2 & 3 & 2 & $2.3(0.5)$ \\
\hline CAT (score) $\div$ mean (SD) & $29.5(2.1)$ & 40 & $34.5(6.3)$ & $34.3(9.9)$ \\
\hline Current/former/non smoker (\%) & $0 / 33,3 / 0$ & 0/0/0 & $50 / 0 / 0$ & $16,6 / 16,6 / 0$ \\
\hline Pack/year $\div$ (years) mean $(\mathrm{SD})$ & 20 & 0 & 34 & $27(7)$ \\
\hline
\end{tabular}

no $\mathrm{S}$ and $\mathrm{Z}$ variants [30]. While in India, genotyping of 200 COPD patients identified two SS (1\%) and one $\mathrm{ZZ}$ patient $(0.5 \%)$ [31].

On the other hand, an investigation of 158 healthy subjects in Saudi Arabia showed that $2.53 \%$ were heterozygous for the $\mathrm{Z}$ mutation, $11.39 \%$ were heterozygous for the $\mathrm{S}$ mutation and 3.8\% had an SZ genotype [32]. The high frequency in Saudi Arabia could be explained by movement of people over time to major cities in that country [12].

Kazakhstan is a Central Asian country, which has historically been inhabited by nomadic tribes. Indeed, the indigenous population is made up of Kazakhs, a Turkish-speaking people. Anthropologically, Kazakhs belong to the Southern Siberian lineage, the majority of whom have racially-diagnostic features intermediate between Caucasians and Mongoloids, with some predominant Mongoloid components [33, 34].

Recent investigations in the Kazakh population confirmed a remarkable frequency of AATD variants in the general population and healthy subjects. The IEF method in an ultra-thin polyacrylamide gel identified variants of alpha1-antitrypsin in 218 indigenous residents from three ethno-historical regions of the Kazakh Soviet Socialist Republic. The frequencies of alleles - PIM1, PIM2, PIM3 - in the total sample were $0.8477,0.1372$ and 0.0106 , respectively, the overall frequency of rare phenotypes (PIN and PIZ) was 0.0046 [35], which however resulted smaller than the frequency of rare pathological genotypes detected in the present paper (0.032). This discrepancy could mainly be explained by the more sensible and updated diagnostic approach we used.

An intergroup variability analysis of phenotypes and allele frequencies of alpha1-antitrypsin showed a clear local diversity. PIM1 frequency among Kazakh residents of the Northern-central area was significantly lower, while the PIM2 frequency was significantly higher than in the Southeastern and Western regions. Accordingly, the PIM3 frequency in the sample did not differ. The results were compared with the published data on alpha-1 antitrypsin polymorphisms in Eurasian populations. The PIM1 and PIM2 allele frequencies in Kazakhs differed from the corresponding average values for both Caucasian and Mongoloid groups. However, they were intermediate between Caucasian and Mongoloid frequency estimates, as might be expected considering the mixed origin of the Kazakh people and the Kazakhstan geographical position and its boundary between Europe and Asia [34].

The present screening of COPD Kazakh patients showed that $\mathrm{Z}$ and $\mathrm{S}$ allele frequencies (although low) were not that different from other studies on Caucasian populations. The percentage of $\mathrm{PI}^{*} \mathrm{MZ}$ cases $(1.6 \%)$ detected was half that of the Spanish study performed in the primary care setting in COPD patients. In that study, nineteen patients out of 596 (3.2\%) were carriers of the allelic variant $Z$, two of whom were homozygous for PiZZ and one heterozygous for PiSZ [36].

In this study, we extended the SERPINA1 gene investigation to variants not detectable by $\mathrm{PI}^{*} \mathrm{~S}$ and $\mathrm{PI}{ }^{*} \mathrm{Z}$ genotyping. With this strategy, we found two samples with the rare deficiency variant I (frequency 1.1\%). The I mutation occurs at the residue, arginine 39, which is involved in the formation of an ionic bond with glutamic acid 264 [37]. Although no subjects with severe AATD deficiency were detected in this study, we found six out of 187 (5\%) subjects positive for so called "intermediate genetic AAT deficiency" [mean (SD) AAT level: $0.85 \mathrm{~g} / \mathrm{L}(0.17)]$. These findings are consistent with the hypothesis that intermediate 
AATD, such as PI*MZ and PI*MI, represents a risk factor for developing COPD [38, 39]. An interesting meta-analysis [40] reported that the increased risk for COPD in PI*MZ heterozygous individuals (OR for $\mathrm{PI}^{*} \mathrm{MZ}$ versus PI*MM (normal genotype) was 2.31 (95\% CI 1.60 to 3.35). These data underscore the importance of genetic screening for AATD in Kazakhstan, as it permits the identification of a rarely identified disorder.

We compared our data with other studies on patients with COPD. The largest percentage $(4.2 \%)$ of rare mutations was found in the study by Sabri et al. on Tunisian patients with COPD. In our study, the frequency of the rare mutation PIMI was $1.1 \%$ (Table 4). To characterize the genetic origin of the Kazakhs in relation to Europeans and Mongoloids, the polymorphisms of SERPINA1 gene need to be studied among the peoples of Tunguss, Turkic and Mongol origin, whose ancestors participated in the formation of the South Siberian anthropological Kazakh [33, 41]. On the contrary, the analysis of people with Chinese origin could have less importance regarding this goal, since the Chinese were not nomads and moved to already conquered countries. Thus, past population migrations appears to be the most reasonable explanation for transport of deficiency alleles from Europe to Kazakhstan.

\section{Conclusions}

The present study demonstrates that genetic AATD is present in the Kazakh population. Furthermore, this investigation, performed for the first time with current diagnostic standards in a Kazakh population with COPD, highlights the implication of AATD in the development of COPD. The so-called 'rare' AAT alleles may not be as rare as expected. We propose that the rare AAT deficiency variant frequency in Kazakhstan may exceed that observed in this pilot study. This assumption requires verification by casefinding in additional Kazakh cohorts, and could

Table 4 Comparison of the current study with data on COPD cohorts from the literature

\begin{tabular}{|c|c|c|c|c|c|c|c|c|}
\hline \multirow{2}{*}{$\begin{array}{l}\text { Phenotype Studies } \\
\text { ( } n=\text { number of patients) }\end{array}$} & \multirow{2}{*}{$\begin{array}{l}\text { Normal } \\
\text { phenotype } \\
\text { PiMM n \% }\end{array}$} & \multicolumn{6}{|c|}{ Alpha-1-antitrypsin mutation Phenotypes } & \multirow[t]{2}{*}{ Inclusion criteria } \\
\hline & & $\begin{array}{l}\mathrm{PiMZ} \\
n \%\end{array}$ & $\begin{array}{l}\text { PiMS } \\
n \%\end{array}$ & $\begin{array}{l}\text { PiSS } \\
n \%\end{array}$ & $\begin{array}{l}\text { PiSZ } \\
n \%\end{array}$ & $\begin{array}{l}\mathrm{PiZZ} \\
n \%\end{array}$ & $\begin{array}{l}\text { Other phenotypes } \\
n \%\end{array}$ & \\
\hline $\begin{array}{l}\text { Mittman et al. } 1974 \text { [43] } \\
(n=240) \\
\text { USA }\end{array}$ & $\begin{array}{l}194 \\
80,8 \%\end{array}$ & $\begin{array}{l}20 \\
8,4 \%\end{array}$ & $\begin{array}{l}17 \\
7,1 \%\end{array}$ & $\begin{array}{l}1 \\
0,4 \%\end{array}$ & $\begin{array}{l}2 \\
0,8 \%\end{array}$ & $\begin{array}{l}6 \\
2,5 \%\end{array}$ & $\begin{array}{l}0 \\
0 \%\end{array}$ & $\begin{array}{l}\text { Chronic bronchitis and/or } \\
\text { emphysema }\end{array}$ \\
\hline $\begin{array}{l}\text { Cox et al. } 1976[44] \\
(n=163) \\
\text { USA }\end{array}$ & $\begin{array}{l}139 \\
85,3 \%\end{array}$ & $\begin{array}{l}8 \\
4,9 \%\end{array}$ & $\begin{array}{l}7 \\
4,3 \%\end{array}$ & $\begin{array}{l}0 \\
0 \%\end{array}$ & $\begin{array}{l}0 \\
0 \%\end{array}$ & $\begin{array}{l}8 \\
4,9 \%\end{array}$ & $\begin{array}{l}1 \\
0,6 \%\end{array}$ & $\begin{array}{l}\text { COPD and aged over } \\
18 \text { years }\end{array}$ \\
\hline $\begin{array}{l}\text { Liebermann et al. } 1986 \text { [45] } \\
(n=965) \\
\text { USA }\end{array}$ & not indicated & $\begin{array}{l}74 \\
7,7 \%\end{array}$ & $\begin{array}{l}86 \\
8,9 \%\end{array}$ & $\begin{array}{l}3 \\
0,3 \%\end{array}$ & $\begin{array}{l}3 \\
0,3 \%\end{array}$ & $\begin{array}{l}18 \\
1,9 \%\end{array}$ & not indicated & COPD \\
\hline $\begin{array}{l}\text { Sitkauskiene et al. } 2008 \text { [46] } \\
(n=1167) \\
\text { Lithuania }\end{array}$ & not indicated & $\begin{array}{l}40 \\
3,4 \%\end{array}$ & $\begin{array}{l}39 \\
3,3 \%\end{array}$ & $\begin{array}{l}1 \\
0,1 \%\end{array}$ & $\begin{array}{l}3 \\
0,3 \%\end{array}$ & $\begin{array}{l}8 \\
0,7 \%\end{array}$ & $\begin{array}{l}0 \\
0 \%\end{array}$ & COPD according to GOLD \\
\hline $\begin{array}{l}\text { Sabri Denden et al. } 2008 \text { [47] } \\
(n=120) \\
\text { Tunisia }\end{array}$ & $\begin{array}{l}114 \\
95 \%\end{array}$ & $\begin{array}{l}1 \\
0.83 \%\end{array}$ & $\begin{array}{l}0 \\
0 \%\end{array}$ & $\begin{array}{l}0 \\
0 \%\end{array}$ & $\begin{array}{l}0 \\
0 \%\end{array}$ & $\begin{array}{l}0 \\
0 \%\end{array}$ & $\begin{array}{l}5 \\
4,2 \%\end{array}$ & COPD according to GOLD \\
\hline $\begin{array}{l}\text { Molina et al. [36] } 2009 \\
(n=596) \\
\text { Spain }\end{array}$ & $\begin{array}{l}487 \\
81,7 \%\end{array}$ & $\begin{array}{l}16 \\
2,7 \%\end{array}$ & $\begin{array}{l}80 \\
13,4 \%\end{array}$ & $\begin{array}{l}10 \\
1,7 \%\end{array}$ & $\begin{array}{l}1 \\
0,2 \%\end{array}$ & $\begin{array}{l}2 \\
0,3 \%\end{array}$ & $\begin{array}{l}0 \\
0 \%\end{array}$ & COPD according to GOLD \\
\hline $\begin{array}{l}\text { Novak T et al. 2011, [48] } \\
(n=105) \\
\text { Germany }\end{array}$ & $\begin{array}{l}94 \\
89,5 \%\end{array}$ & $\begin{array}{l}4 \\
3,8 \%\end{array}$ & $\begin{array}{l}6 \\
5,7 \%\end{array}$ & $\begin{array}{l}0 \\
0 \%\end{array}$ & $\begin{array}{l}0 \\
0 \%\end{array}$ & $1,0 \%$ & $\begin{array}{l}0 \\
0 \%\end{array}$ & COPD according to GOLD \\
\hline $\begin{array}{l}\text { Sydykova S. et al. } 2008 \text { [49] } \\
\text { Kirgizstan } \\
(n=125)\end{array}$ & $\begin{array}{l}139 \\
97,2 \%\end{array}$ & $\begin{array}{l}3 \\
2,1 \%\end{array}$ & $\begin{array}{l}0 \\
0 \%\end{array}$ & $\begin{array}{l}0 \\
0 \%\end{array}$ & $\begin{array}{l}0 \\
0 \%\end{array}$ & $\begin{array}{l}1 \\
0,7 \%\end{array}$ & $\begin{array}{l}0 \\
0 \%\end{array}$ & COPD according to GOLD \\
\hline $\begin{array}{l}\text { Rahaghi et al. } 2012 \text { [50] } \\
(n=3152) \\
\text { USA }\end{array}$ & $\begin{array}{l}2780 \\
88,2 \%\end{array}$ & $\begin{array}{l}124 \\
3,9 \%\end{array}$ & $\begin{array}{l}225 \\
7,1 \%\end{array}$ & $\begin{array}{l}9 \\
0,28 \%\end{array}$ & $\begin{array}{l}10 \\
0,32 \%\end{array}$ & $\begin{array}{l}10 \\
0,32 \%\end{array}$ & $\begin{array}{l}0 \\
0 \%\end{array}$ & $\begin{array}{l}\text { Case-finding in GOLD II-IV } \\
\text { sent for Spirometry excluded } \\
\text { previously tested patients }\end{array}$ \\
\hline $\begin{array}{l}\text { This study } \\
(n=187) \\
\text { Kazakhstan }\end{array}$ & $\begin{array}{l}181 \\
96.8\end{array}$ & $\begin{array}{l}3 \\
1,6 \%\end{array}$ & $\begin{array}{l}1 \\
0,5 \%\end{array}$ & $\begin{array}{l}0 \\
0 \%\end{array}$ & $\begin{array}{l}0 \\
0 \%\end{array}$ & $\begin{array}{l}0 \\
0 \%\end{array}$ & $\begin{array}{l}2 \\
1,1 \%\end{array}$ & COPD according to GOLD \\
\hline
\end{tabular}


support the want of a target screening for AATD in Kazakhstan, a country where, although this disease has been recognized as rare by Ministry of Health in 2015, a program of detection and specific treatments is still lacking.

\section{Abbreviations}

AAT: Alpha1-antitrypsin; AATD: Alpha1-antitrypsin deficiency; BMI: Body mass index; CAT: COPD assessment test; COPD: Chronic obstructive pulmonary disease; DBS: Dried blood spot; DNA: Deoxyribonucleic acid; ERS: European Respiratory Society; FEV ${ }_{1}$ : Forced expiratory volume in one second; FVC: Forced vital capacity; GOLD: Global initiative for chronic obstructive lung disease; IEF: Isoelectrofocusing; kDa: Kilodalton; MRC: Medical research council scale; NE: Neuthrophil elastase; SD: Standard deviation; SERPINA1: Serine (Or Cysteine) proteinase inhibitor; WHO: World Health Organization

\section{Aknowledgments}

Not applicable.

\section{Funding}

Dr. Ardak Zhumagaliyeva is the recipient of a European Respiratory Society Fellowship (STRTF 2015), therefore the results of this study were presented at European Respiratory Congress in 2016 [42] We gratefully acknowledge the support of the European Respiratory Society, Fellowship STRTF 2015-8199.

\section{Availability of data and materials}

Please contact author for data requests.

\section{Authors' contributions}

AZh, GN, IF, MZ, AC drafted the manuscript and revised it critically for intellectual content. AD substantially contributed to the data analysis and interpretation. AZh, MG, VK and VB participated in laboratory investigations. IF, SO, MZ, AC, CV, TG, LK supervised the study process, revised and edited the final manuscript. All authors read and approved the final manuscript.

\section{Ethics approval and consent to participate}

This study was approved by the local Ethical Committee (№2, 13.11.2013), Hospital of Semey (East Kazakhstan region).

\section{Consent for publication}

Not applicable.

\section{Competing interests}

The authors have no competing interests to declare.

\section{Publisher's Note}

Springer Nature remains neutral with regard to jurisdictional claims in published maps and institutional affiliations.

\section{Author details}

${ }^{1}$ Semey State Medical University, Semey, Kazakhstan. ${ }^{2}$ Center for Diagnosis of Inherited Alpha1-antitrypsin Deficiency, Dept of Internal Medicine and Therapeutics Pneumology Unit, IRCCS San Matteo Hospital Foundation University of Pavia, Piazza Golgi 1, 27100 Pavia, Italy. ${ }^{3}$ University Clinic of Marburg and Gissen, Center for Research alpha-1-antitrypsin deficiency, Marburg, Germany. ${ }^{4}$ Dept of Internal Medicine and Therapeutics, Pneumology Unit, University of Pavia, Pavia, Italy. ${ }^{5}$ Kazakh Medical University of Continuing Education, Almaty, Kazakhstan. ${ }^{6}$ Statistics Department Fondazione IRCCS Policlinico San Matteo, Pavia, Italy.

Received: 15 June 2017 Accepted: 24 August 2017

Published online: 25 October 2017

\section{References}

1. WHO (2008) World Health Statistics 2008. http://www.who.int/whosis/ whostat/2008/. Last access 28 August 2017.

2. Kozlova I. New in the diagnosis and treatment of COPD. Kazakhstan Med J. 2012;6:13-5.
3. Brantly M, Nukiwa T, Crystal RG. Molecular basis of alpha-1-antitrypsin deficiency. Am J Med. 1988;84:13-31.

4. Stolk J, Seersholm N, Kalsheker N. Alpha1-antitrypsin deficiency: current perspective on research, diagnosis, and management. Int J Chron Obstruct Pulmon Dis. 2006;1:151-60.

5. Laurell CB, Eriksson S. The elctrophoretic a1-globulin pattern of serum in a1antitrypsin deficiency. Scand J Clin Lab Invest. 1963;15:132-40.

6. Silverman EK, Sandhaus RA. Clinical practice. Alpha1-antitrypsin deficiency. N Engl J Med. 2009;360:2749-57.

7. Stoller JK, Aboussouan L.S: $a_{1}$-antitrypsin deficiency. Lancet. 2005,365:2225-36.

8. Lomas DA, Mahadeva R. Alpha1-antitrypsin polymerization and the serpinopathies: pathobiology and prospects for therapy. J Klin Invest. 2002; 110:1585-90.

9. Ferrarotti I, Scavini R, Campo I, Ottaviani S, Zorzetto M, Gorrini M, Luisetti M. Laboratory diagnosis of alpha1-antitrypsin deficiency. Transl Res. 2007;150:267-74.

10. Luisetti M, Seersholm N. Alpha1-antitrypsin deficiency. I: Epidemiology of Alpha1-antitrypsin deficiency. Thorax. 2004;54:164-9.

11. de Serres FJ. Worldwide racial and ethnic distribution of alpha1-antitrypsin deficiency. Summary of an analysis of published genetic epidemiology surveys. Chest. 2002:122:1818-29.

12. de Serres FJ, Blanco I, Fernandes-Bustillo E. PIS and PIZ Alpha1-antitrypsin deficiency worldwide. A review of existing genetic epidemiological data. Monaldi Arch Chest Dis. 2007;67:184-208.

13. Rodriguez-Frias F, Miravitlles M, Vidal R, Camos S, Jardi R. Rare alpha-1antitrypsin variants: are they really so rare? Ther Adv Respir Dis. 2012;6:79-85.

14. American Thoracic Society/European Respiratory Society Statement. Standards for the diagnosis and management of individuals with alpha1antitrypsin deficiency. Am J Respir Crit Care Med. 2003;168:818-900.

15. De Serres FJ, Blanco I, Fernandez-Bustillo E. Estimating the risk for alpha-1 antitrypsin deficiency among COPD patients: evidence supporting targeted screening. COPD. 2006:3:133-9.

16. de Serres FJ, Blanco I, Fernandez-Bustillo E. Health implications of alpha1antitrypsin deficiency in Sub-Sahara African countries and their emigrants in Europe and the New World. Genet Med. 2005;7:175-84.

17. de Serres FJ, Blanco I, Fernandez-Bustillo E. Genetic epidemiology of alpha-1 antitrypsin deficiency in North America and Australia/New Zealand: Australia, Canada, New Zealand and the United States of America. Clin Genet. 2003;64:382-97.

18. de Serres FJ, Blanco I, Fernández-Bustillo E. Estimated numbers and prevalence of P ${ }^{*} \mathrm{~S}$ and $\mathrm{PI} Z \mathrm{Z}$ deficiency alleles of $\mathrm{a}_{1}$-antitrypsindeficiency in Asia. EurRespir J. 2006:28:1091-9.

19. de Serres F, Blanco I, Bustillo EF. Genetic epidemiology of alpha-1antitrypsin deficiency: France, Italy, Portugal, and Spain. Clin Genet. 2003:63:490-509.

20. Global strategy for the diagnosis, management, and prevention of chronic obstructive pulmonary disease [http://goldcopd.org/gold-reports/]. Last access 28 August, 2017.

21. European Respiratory Society. Standardized lung function testing. Lung volumes and forced ventilatory flows: 1993 update. Eur Respir J. 1993;6:5-40.

22. Gorrini M, Ferrarotti I, Lupi A, Bosoni T, Mazzola P, et al. Validation of a rapid simple method to measure alpha1-antitrypsin in human dried blood spots. Clin Chem. 2006:52:899-901.

23. Ferrarotti I, Zorzetto M, Scabini R, Mazzola P, Campo I, Luisetti M. A novel method for rapid genotypic identification of alpha1-antitrypsin variants. Diagn Mol Pathol. 2004;12:160-3.

24. Bals R, Koczulla R, Kotke V, Andress J, Blackert K, Vogelmeier C. Identification of individuals with alpha-1-antitrypsin deficiency by a targeted screening program. Respir Med. 2007;101:1708-14.

25. Zerimech F, Hennache G, Bellon F, Barouh G, Jacques Lafitte J, Porchet N, Balduyck M. Evaluation of a new Sebia isoelectric focusing kit for alpha 1-antitrypsin phenotyping with the Hydrasys System. Clin Chem Lab Med. 2008:46:260-3.

26. de Serres FJ, Blanco I. Prevalence of alpha1-antitrypsin deficiency alleles PI*S and $\mathrm{PI}^{*} \mathrm{Z}$ worldwide and effective screening for each of the five phenotypic classes PI*MS, PI*MZ, PI*SS, PI*SZ, and PI*ZZ: a comprehensive review. Ther Adv Respir Dis. 2012;6:277-95.

27. Kwok JS, Lawton JW, Yew WW, Chau CH, Lee J, Wong PC. Protease inhibitor phenotypes and serum alpha-1-antitrypsin levels in patients with COPD: a study from Hong Kong. Respirology. 2004;9:265-70.

28. Zhu YJ. Epidemiological survey of chronic obstructive pulmonary disease and alpha-1-deficiency in China. Respirology. 2001;6:513-5. 
29. Shim YS. Epidemiological survey of chronic obstructive pulmonary disease and alpha-1 antitrypsin deficiency in Korea. Respirology. 2001;6:S9-11.

30. Geramizadeh B, Jowkar Z, Karami L, Masoumpour M, Mehrabi S, Ghayoumi M. Alpha-1 Antitrypsin Deficiency in Iranian Patients with Chronic Obstructive Pulmonary Disease. Iran Red Cres Med J. 2013;15:e7508.

31. Sobti RC, Thakur H, Gupta L, Janmeja AK, Seth A, Singh SK. Polymorphisms in the HPC/ELAC-2 and alpha 1-antitrypsin genes that correlate with human diseases in a North Indian population. Mol Biol Rep. 2011;38:3137-44.

32. Aljarallah B, Ali A, Dowaidar M, Settin A. Prevalence of alpha-1-antitrypsin gene mutations in Saudi Arabia. Saudi J Gastroenterol. 2011;17:256-60.

33. Ismagulov A. Ethnic anthropology of Kazakhstan. Almaty; 1982. p. 229.

34. Roginskii YY, Levin MG. Anthropology. High School; 1978. p. 528.

35. Petrishev VN, Lebedeva IA, Shneider lu V. Genetic polymorphism of the alpha 1-antitrypsin system in the native population of the Kazakh.SSR. Genetika. 1987:23:2257-64.

36. Molina J, Flor X, Garcia R, Timiraos R, Tirado-Conde G, Miravitlles M. The IDDEA project: a strategy for the detection of alpha-1 antitrypsin deficiency in COPD patients in the primary care setting. Adv Respir Dis. 2011;5:237-43.

37. Sebetan IM. a new allele in the alpha-1-antitrypsin system. Hum Hered. 1992;42:206-8

38. Molloy K, Hersh CP, Morris VB, Carroll TP, O'Connor CA, Lasky-Su JA, et al. Clarification of the risk of chronic obstructive pulmonary disease in a1antitrypsin deficiency PiMZ heterozygotes. Am J Respir Crit Care Med. 2014; 189:419-27.

39. Baur X, Bencze K. Initial study of familial alpha---proteinase inhibitor deficiency including a rare proteinase inhibitor phenotype (IZ). Respiration. 1987:51:188-95.

40. Hersh CP, Dahl M, Ly NP, Berkey CS, Nordestgaard BG, Silverman EK. Chronic obstructive pulmonary disease in a1-antitrypsin PI MZ heterozygotes: a meta-analysis. Thorax. 2004;59:843-9.

41. Ginzburg W, Trofimova TA. Paleoanthropology of Central Asia.Moscow; 1972. p. 371.

42. Zhumagaliyeva A, Gorrini M, Vogelmeier C, Corsico A, Karazhanova L, Greulich T, et al. Alpha-1-antitrypsin deficiency in Kazakh subjects with COPD. Eur Respir J. 2016;48:PA3669.

43. Mittman C, Lieberman J, Rumsfeld J. Prevalence of abnormal protease inhibitor phenotypes in patients with chronic obstructive lung disease. Am Rev Respir Dis. 1974;109:295-6.

44. Cox DW, Hoeppner VH, Levison H. Protease inhibitors in patients with chronic obstructive pulmonary disease: the alpha-antitrypsin heterozygote controversy. Am Rev Respir Dis. 1976;113:601-6.

45. Lieberman J, Winter B, Sastre A. Alpha 1-antitrypsin Pi-types in 965 COPD patients. Chest. 1986;89:370-3.

46. Sitkauskiene B, Serapinas D, Blanco I, Fernández-Bustillo E, Janciauskiene S, Sakalauskas R. Screening for alpha1-antitrypsin deficiency in Lithuanian patients with COPD. Respir Med. 2008;102:1654-8.

47. Denden S, Zorzetto M, Amri F, Knani J, Ottaviani S, Scabini R, Gorrini M, Ferrarotti I, Campo I, Chibani JB, Khelil AH, Luisetti M. Screening for Alpha 1 antitrypsin deficiency in Tunisian subjects with obstructive lung disease: a feasibility report. Orphanet J Rare Dis. 2009;4:12.

48. Nowak T. Screening of COPD patients for alpha-1 antitrypsin deficiency. Dissertation to obtain the academic degree of doctor medicine. The Friedrich-Schiller University of Jena. 2011104.

49. Sydykova SJ, Alymbaeva MJ, Vogelmeier C, Heine R, Brimkulov NN. Alpha 1antitrypsin levels and phenotypes in COPD patients in Kyrgyz population. Eur Respir J. 2008;32:S52.

50. Rahaghi F, Ortega I, Rahaghi N, Oliveira E, Ramirez J, Smolley L, Stoller JK. Physician alert suggesting alpha-1 antitrypsin deficiency testing in pulmonary function test (PFT) results. COPD. 2009;6:26-30.

\section{Submit your next manuscript to BioMed Central and we will help you at every step:}

- We accept pre-submission inquiries

- Our selector tool helps you to find the most relevant journal

- We provide round the clock customer support

- Convenient online submission

- Thorough peer review

- Inclusion in PubMed and all major indexing services

- Maximum visibility for your research

Submit your manuscript at www.biomedcentral.com/submit
Biomed Central 